\title{
Metonyms and Metaphor: The Rhetorical Redescription of Public Interest for the
} International Accounting Standards Board

\begin{abstract}
We focus on what invoking the public interest 'does' for the International Accounting Standards Board [IASB], as a trans-national, private regulator. Our study focuses on a snapshot from 2010-2015 post the global financial crisis, as the IASB and the International Financial Reporting Standards Foundation [IFRSF] suffered a legitimacy crisis. We are interested in how the IASB restated the meaning of the public interest and the impact of invoking different conceptions of public interest. With respect to metonyms, this paper employs rhetorical redescription to identify the implications of defining the public interest as procedural due process, substantive due process and as outcome-focused. At the same time, through careful interpretation, the paper examines the rival metaphors attached to meanings of the public interest. By examining what invoking the public interest 'does', our ontological analysis illustrates how these redescriptions constituted a rhetorical strategy for organizational legitimacy, how the meanings operated as a form of 'ideological cover', and the political impact of constructing the 'public interest' as a floating signifier. We argue that these strategies operated to reinstitute the technocratic power of the IASB.
\end{abstract}

\section{Keywords}

Public Interest, International Accounting Standards Board, Retroduction, Rhetorical Redescription, Metonym, Metaphor 


\section{Introduction}

The International Accounting Standards Board [IASB] formed in 2001 as a private, not-forprofit, transnational regulator of accounting and financial reporting. It develops accounting standards for use by listed entities (and recently non-listed entities such as Small and Medium Sized Entities), with the objective of facilitating global capital movement through comparability (for a history, see Camfferman and Zeff 2007). The IASB seek consistency and market efficiency, as the 'world's financial markets are borderless' (Pacter 2015, 24). The IASBs constitution recognizes the 'public interest', by seeking to:

...develop, in the public interest, a single set of high quality global accounting standards that provide high quality, transparent and comparable information in general purpose financial statements (IASB 2001).

The IASB, consisting of 14 board members, operates an internal network governance model (Figure 1 depicts the organizational structure) interconnected with broader international financial institutions (the World Bank, IMF, financial markets, governments and the G20).

Insert Figure 1 about here

The IASB employ due process guidelines in developing accounting standards, which they consider 'open', 'participatory' and 'transparent' (IFRSF 2013). Currently, 119 countries adopted International Financial Reporting Standards-based (IFRS) financial reporting, (but not the US) and 85 countries adopted IFRS for SMEs.

Significant literature focuses on how the IASB conceives the 'public interest' (Gallhofer and Haslam 2003, 2007; Gaffikin 2008). In this paper, we do not suggest improvements as to how the IASB should approach the public interest (Botzem 2012); we do not focus normatively on how the IASB should use the public interest (Gallhofer and Haslam 2003) and we do not 
interrogate what the public interest means according to regulatory or political theory (Bozeman 2007). We focus retroductively on what invoking the public interest 'does' for the IASB (Mol and Law 2004; Frezatti, D. Carter, and Barroso 2014), by examining a snapshot - 2010-2015 - where the IASB and the IFRS Foundation [IFRSF] invoke four articulations (in six particular sentences [tropes]) of the public interest. We employ rhetorical redescription (explained in methodology) to understand the impact of each articulation.

We chose to focus on 2010-2015 due to accounting regulation being subject to unmatched political scrutiny following the global financial crisis (GFC) (Botzem 2012, 1-2):

Vibrant discussions of the reasons [for the GFC] soon emerged ... Political reactions to the financial crisis moved accounting standards and transnational standardization bodies into a spotlight that they had successfully avoided for decades.

This 'spotlight' threatened the legitimacy of the IASB (Howarth 2013; Howarth, Glynos, and Griggs 2016). Threats to legitimacy arising from the GFC included concerns with accounting standards such as Fair Value Accounting (Erb and Pelger 2015) and criticisms of the IASB's approach to the 'public interest' (Botzem and Quack 2009; Quack 2010), governance, transparency and due process (Erb and Pelger 2015; Quack 2010; Porter 2014). Botzem (2012, 2014) illustrates that the IASB responded to these threats as accounting regulation was a mainstream political issue. However, the IASB's approach to the 'public interest' continues to receive criticism by academics, users, investors, think-tanks and Governments (Richardson and Eberlein 2011; Wingard, Bosman and Amisi 2016; Pelger and Spieß 2017).

A key 'moment', post-GFC, was when the G20 challenged the IASB (Botzem 2014). Deloitte (2009) recorded:

The Declaration on Strengthening the Financial System issued by the leaders of the G20 following their meeting in London on 2 April 2009 calls on the accounting standard setters 
to improve standards for determining the fair values of financial instruments in illiquid markets and to take other actions regarding complexity of financial reporting, provisioning, and off balance sheet financing, among other matters

... within the framework of the independent accounting standard setting process, improve involvement of stakeholders, including prudential regulators and emerging markets, through the IASB's constitutional review.

In response, the IASB committed to 'taking action on each of the items recommended by the G20 ... in order to ensure globally consistent and appropriate responses to the crisis' (Deloitte 2009). This contextualizes why the IASB responded to criticisms of the 'public interest' (Botzem 2014) and the IFRSF $(2015,1)$ reinforced this when it explained:

Some have expressed concern that the IFRSF is overly exposed to private, commercial interests and has insufficient regard for the public interest. They argue that these perceived fragilities in its governance also permeate the quality of the IASB's standard-setting. In their view, IFRS are beneath a veneer of technocratic neutrality, in reality too closely geared towards meeting the needs of short-term investors. By supposedly relying excessively on market-value-based fair-value accounting, the IASB is seen as having too little regard for prudence in accounting.

Thus, from 2010-2015, the IASB and IFRSF revisited its understanding of 'the public interest', re-examining due process, governance structures and changing certain accounting standards (Botzem 2012; Erb and Pelger 2015). For example, Figure 1 illustrates how the IASB responded institutionally through introducing the Monitoring Board as an oversight body (Botzem 2014, Cooper 2015), which responded to the G20's concern with the 'involvement of stakeholders, including prudential regulators'. Consequently, Botzem $(2012,1-2)$ argues that the IASB had to re-focus on public interest regulation.

The spotlight of the GFC shifted accounting regulation from hidden technocracy to politics (Botzem 2012, 2), as recognized by critical policy literature (Pautz 2016; Scherrer 2011). Similarly, Glynos, Klimecki and Willmott (2015) emphasize the centrality of technocracy in explaining the social logics of accounting and accountability. However, the GFC-crisis presented a strategic moment for the IASB to re-center their technocratic power as a selfregulator, as it 'recognize[d] that its Standards are of great value for the public at large, in all 
its guises' (IFRSF 2015, 1; Botzem and Hofmann 2010). Moreover, this focus on what the public interest 'does' for the IASB constitutes a broader contribution to policy literature as it illustrates risks with regulatory and governmental bodies drawing on accounting while ignoring the social and political impacts of accounting, as well as constituting a cautionary tale for regulatory bodies acting in the public interest (Black 2008; Quack 2010). Given this, it is important to study the impact of changes in the IASB's conception of the public interest.

\section{An ontology of what invoking the public interest 'does'}

Accounting standard setting mirrors traditional public interest debates in regulation (Black 2002). Camfferman and Zeff $(2007,2)$ suggest: 'Our main premise ... is that we accept the [...] stated purpose of setting accounting standards in the public interest'. However, certain scholars within accounting question what is or what should be the role of the 'public interest' in accounting standard setting. ${ }^{1}$ For regulatory theory, the 'public interest' is complicated (Posner 1974; Peltzman 1976; Howarth 2013). Accounting literature reflects this (Gallhofer and Haslam 2003, 2007; Gaffikin 2008; Dellaportas and Davenport 2008), by demonstrating that the 'public interest' concept is a messy, overused, 'throw-away' device (Chiapello 2007; Botzem and Quack 2009; Sayre 1958). Politically, Catlett $(1960,44)$ argues that 'accounting has been created and developed to achieve various desired objectives', while Mitchell et al. $(1994,48)$ argue that the 'public interest' in accounting is 'little more than a smokescreen ... for the pursuit and protection of sectional interests'. Accounting literature is concerned with participation, diversity and geographical representation within public interest discourses, as the current approach enables dominant interests to restrict the public interest to private

\footnotetext{
${ }^{1}$ Accounting regulatory theory followed a Chicago-school economics foundation, resulting in a positivist accounting theory. Key accounts of the history of accounting regulatory theory include Gaffikin (2007; 2008); Deegan and Unerman (2011).
} 
constituents, such as traditional market interests (Gallhofer and Haslam 2007; Cortese, Irvine, and Kaidonis 2010).

Theoretically, the political economy of regulation suggests the trade-off of competing interests:

The essential commodity being transacted in the political market is a transfer of wealth, with constituents on the demand side and their political representatives on the supply side ... the market here, as elsewhere, will distribute more of the good to those whose effective demand is the highest (Peltzman 1976, 212).

Gerboth $(1973,497)$, in agreement, argues: "[i]n the face of conflict between competing interests, rationality as well as prudence lies not in seeking final answers, but rather in compromise - essentially a political process". While the IASB claim they are objective and fair, this claim is problematic, as research illustrates that IASB processes measures are exclusionary and motivated by certain capital market interests (Gallhofer and Haslam 2007; Chiapello and Medjad 2009; Messner 2009). Lazzarato (2012, 100-101) criticizes the IASB by illustrating the violence of financial capital:

[Accounting] dictates to and imposes upon private firms a new "measure" of value, implemented through new international accounting standards...developed in the exclusive interest of investors and shareholders.

Hines (1991) argues that accounting legitimates capitalism through partial and one-sided accounts (Morgan 1988), privileging certain views and silencing others (Suddaby and Greenwood 2005). This mirrors critical policy literature including Green's (2007) account of carbon accounting and Wolcher's (2007) critique of cost-benefit policy-making. Despite this, the misplaced perception of accounting is that it is technical, technocratic and objective (Morgan 1988; Gill 2009).

In stakeholder consultation, the IASB's due process handbook (2006) demonstrates an initial procedural due process focus (Economic and Financial Affairs Council 2006), which reflects 
Burkhead and Miner (1971, 232), who argue that the 'public interest' is constrained to where '[t]he rules of the game are important, not just the specific, isolated outcomes' (Bozeman 2007). However, for Horwitz $(1989,131)$, the 'public interest' 'becomes a terrain of struggle', which results in private interests being favored, as Black (2002, 2-3) illustrates that regulators are insufficiently motivated to regulate in the public interest and powerful groups benefit (Posner 1974, 344). The technocratic nature of accounting regulation downplays the tension with 'public interest' regulation between process and deeper social and political implications (Botzem 2012).

'Public interest' research in policy recognizes this tension (see, Henry 2015; Pautz 2016; Wagenaar 2012), as the veil of technocracy obscures the political nature of technocratic governance (Jennings 2011; Lövbrand and Stripple 2011). Laarson (2013) and Shaw et al., (2015) argue that the influence of private interests and challenges of due process limit the effectiveness of the public interest in self-regulatory environments. Furthermore, P. Carter (2011) argues that New Public Management influences a shift from public interest to technocracy. The impact of this is to weaken the credibility of the IASB's claim to accountability and the 'public interest', because although they employ democratic logics through 'representation', there is little evidence that the participation circle extends beyond limited capital market interests (Gallhofer and Haslam 2007). Quack (2010), in reflecting upon the GFC, identifies that legitimacy is produced, maintained and challenged in transnational governance, but this depends upon how claims are received and responded to by the public. Consequently, the GFC challenged the legitimacy of transnational policy makers, as there were no normative standards by which legitimacy was measurable (Quack 2010, 7). 
While this short summary illustrates that the 'public interest' is complicated, the literature tends to focus descriptively on what the 'public interest' is. We adopt an ontic inquiry focusing on what the 'public interest' 'does' for the IASB and IFRSF (studying 'the political') (Mol and Law 2004). The focus on what the 'public interest' does is material: 'this is a measure of what “counts" as knowledge' (Frezatti, D. Carter and Barroso 2014, 435). Consequently, by examining what the competing public interest tropes $d o$ for the IASB and the IFRSF, this provides the methodological foundation for our study.

\section{Notes on Methodology}

\section{Retroduction and redescriptions}

Our work adds to post-structural literature using 'retroduction' (Howarth and Griggs 2006; Howarth, Glynos and Griggs 2016). We focus on the social 'fact' that from 2010-2015, the IASB and IFRSF invoked four articulations of the public interest (Table 1 details published IFRSF documents with the phrase, 'public interest'). Glynos and Howarth (2007) argue that retroduction focuses on making phenomena intelligible. For social science, ${ }^{2}$ retroduction 'amounts to...observing a fact and then professing to say what...it was that gave rise to the fact' (Sayer 1979, 116). Ontologically, Glynos and Howarth (2007, 47) suggest this is articulatory 'in which the sense and meaning of explanatory categories grow organically and contingently in the very process of their application'. Thus, we apply retroduction to interrogate articulations of the public interest by employing the technique of rhetorical redescription (Glynos and Howarth 2007).

With reference to methodology decisions in Suddaby and Greenwood (2005) and Howarth and

\footnotetext{
${ }^{2}$ This differs to 'retroduction' in the critical realist sense (Modell 2017).
} 
Griggs (2006), we identified four unique conceptions of the 'public interest' from 2010-2015, and as the IASBs 'public interest' discourse was comparatively stable prior to 2010, this invites interrogation (Botzem 2012). We apply Quintilian's (1920) technique of rhetorical redescription (Skinner 2002), as rhetoric is a “... constitutive aspect of social reality, and its ... analysis [is] an essential part of understanding and explaining social reality (Howarth and Griggs 2006, 28).

The competing articulations justify the use of rhetorical redescription, as 'redescriptions' interrogate changes to concepts, as:

a) reconceptualizations revise meanings;

b) renamings change the name of the concept;

c) re-weightings shift significance in meaning; and

d) revaluations alter the normative implications of underlying concepts.

The impact is to 'assign different causes, a different state of mind and a different motive for what was done' (Skinner 2002, 183). ${ }^{3}$ For Quintilian (1920), this 'shadowy underside of politics' involves the substitution of rival, evaluative metaphors or metonyms (Devenney 2002, 176), 'that ... picture an action no less plausibly, but serves at the same time to place it in a contrasting light' (Howarth and Griggs 2006, 11). Griggs and Howarth (2013, 27-28) link rhetoric to hegemony:

... hegemony foregrounds the metonymical dimension of political practices. As a rhetorical strategy, metonymy captures the movement from one thing to another thing which is adjacent of alongside it ... If metaphor links by means of similarity, metonymy connects by contiguity... the role of metaphor is essential, because if a group is to successfully hegemonize the demands and identity of others it must create analogical relations - forms of resemblance - between such demands, while articulating empty signifiers that can partially fix or condense such demands in to a more universal (if ultimately precarious) unity.

For us, rhetorical redescription helps to examine and explain the IASB and IFRSF's employment of rival, evaluative redescriptions of the 'public interest' from 2010-2015.

\footnotetext{
${ }^{3}$ There is similarity here to Derrida's (1998) logic of iteration.
} 


\section{The Retroductive 'Facts'}

The four competing tropes employed by the IASB and the IFRSF include:

a) A 2010 IASB Mission Statement;

b) A 2013 IFRSF publication, entitled 'Due Process Handbook: IASB'4;

c) A 2015 IFRSF publication, entitled, 'Working in the Public Interest: The IFRS Foundation and the IASB ${ }^{\prime},{ }^{5}$ and

d) A 2015 IASB Mission Statement.

We extracted four articulations of the public interest in six tropes and our analysis interprets these redescriptions contextually. However, our analysis involves 're-contextualization': as our interpretation '.. creat[es] an impression of authenticity, of re-contextualization that is interesting, "novel", credible and respectful' (Czarniawska 2000, 19). In conducting this analysis, we individually interpreted the documents in Table 1 based on multiple readings and reflexivity. We wrote our personal interpretations of how the IASB or IFRSF employed the phrase 'the public interest'. We then compared our interpretations and debated when our interpretations were different. In particular (from the analysis terms below), we debated trope 2 and 3 from articulation $\mathrm{C}$, as there was disagreement about the meaning of 'serving' and 'fostering'. Debate was an important sense-making device and initially focused on each document in Table 1, looking for repetition and prominent statements (we are confident that our document archive includes all documents referencing the public interest published by the IASB and IFRSF). The following section identifies the rhetorical redescriptions.

\footnotetext{
${ }^{4}$ This document holds a different status to the Mission statement, but is still important, as it acts to legitimise the IASB and inform the IASB's due process procedures.

5 This was a significant document published by the IASB and is unprecedented. The document is a legitimation device, and illustrates the 'centrality' of the IASBs commitment to the public interest.
} 
...developing, in the public interest, a single set of high quality and principle-based financial reporting standards that are applicable and enforceable on a global basis... (IASB 2010, 2).

We note that the IASB expressed similar sentiments in 2014:

... to develop, in the public interest, a single set of high quality, understandable, enforceable and globally accepted IFRS based upon clearly articulated principles (IFRSF 2014, 1).

Thus, within the three Mission statements $\left(2001,{ }^{6} 2010\right.$ and 2014), there are small iterative differences (Derrida, 1998) concerning the scope application ('global accounting standards', 'on a global basis' and 'globally accepted IFRS'). For example, 'principle-based standards' and 'clearly articulated principles' appear in the 2010 and 2014 Missions. This most likely relates to interactions with US regulators, as the IASB and US Financial Accounting Standards Board considered converging, but this convergence appears to currently be on hold (Botzem 2012). ${ }^{7}$ Despite these variations, the 'public interest' mission remained relatively stable.

\footnotetext{
${ }^{6}$ See the Introduction.

${ }^{7}$ In accounting, there is debate between rules-based standards (the US approach focuses on defined rules) and principles-based standards (the International approach focuses on flexible overarching principles for guiding judgment).
} 


\section{Articulation B: IFRSF: IASB Due Process Handbook: The Public Interest}

Following the publication of the first Due Process Handbook in 2006, the IASB published regular updates (2009, 2011 and 2012). Articulation B is a 2013 update to the Handbook.

The foremost objective of the IFRS Foundation is to develop, in the public interest, a single set of high quality, understandable, enforceable and globally accepted financial reporting standards based on clearly articulated principles ... Those standards should serve investors and other market participants in making informed resource allocation and other economic decisions. The confidence of all users of financial statements in the transparency and integrity of those statements is critically important for the effective functioning of capital markets, efficient capital allocation, global financial stability and sound economic growth ...the IASB conducts its standard-setting process in a transparent manner, considering a wide range of views from interested parties throughout all stages of the development of International Financial Reporting Standards (IFRSs) ... A comprehensive and effective due process is essential to developing high quality IFRSs that serve investors and other users of financial information (IFRSF 2013, 5).

Articulation B draws an equivalence between appropriate due process and producing quality accounting standards (IFRSF 2013). This signifies an important shift, as Articulation A committed to developing accounting standards in the public interest, but Articulation B suggests that the public interest is served through due process.

\section{Articulation C: IFRSF: Working in the Public Interest}

In 2015, the IFRSF published a Working in the Public Interest document. We draw three tropes from this document $(2015,1-3)$.

\section{Trope 1}

We will argue that the standard-setting of the IASB is motivated by a strong sense of public interest as embodied in our Constitution and, more recently, our Mission Statement. While the most active users of financial reporting are investors and creditors in the capital markets, the IASB recognizes that its Standards are of great value for the public at large, in all its guises ... Far from fostering irresponsible profit-reporting and excessive dividend extraction, IFRS aims to impose rigor and discipline on the capital markets, thus promoting trust, economic growth and long-term financial stability. IFRS is also a very cost-effective way of promoting confidence in emerging economies. 


\section{Trope 2}

From its inception, the IFRS has emphasized that IFRS Standards are created to serve the public interest. In our recently published Mission Statement, we define our mission as 'to develop IFRS that bring transparency, accountability and efficiency to financial markets around the world'.

This [mission] statement is further explained as follows:

- IFRS brings transparency by enhancing the international comparability and quality of financial information, enabling investors and other market participants to make informed economic decisions.

- IFRS strengthens accountability by reducing the information gap between the providers of capital and the people to whom they have entrusted their money. Our Standards provide information that is needed to hold management to account. As a source of globally comparable information, IFRS is also of vital importance to regulators around the world.

- IFRS contributes to economic efficiency by helping investors to identify opportunities and risks across the world, thus improving capital allocation. For businesses, the use of a single, trusted accounting language lowers the cost of capital and reduces international reporting costs.

\section{Trope 3}

... Our mission statement sums up our contribution to the public interest as 'fostering trust, growth and long-term financial stability in the global economy'.

In 2015, the IASB and IFRSF changed its organizational structure, as the IFRSF Trustees (the oversight body in Figure 1) introduced the Monitoring Board to facilitate formal interactions with capital market authorities (Botzem 2012, 109). The IFRSF committed in 2010 to a comprehensive organizational review every five years, and thus, Articulation C's 12-page publication corresponds with the first structural five-year review (Botzem 2012, 107).

\section{Articulation D: The IASB: Excluding Special Interests}

Our mission is to develop IFRS that bring transparency, accountability and efficiency to financial markets around the world. Our work serves the public interest by fostering trust, growth and long-term financial stability in the global economy...We are a not-for-profit, public interest organization with oversight by a Monitoring Board of public authorities. Our governance and due process are designed to keep our standard-setting independent from special interests while ensuring accountability to our stakeholders around the world (IASB 2015, 1). 
This quote recognizes the role of the Monitoring Board in serving the public interest, as the Monitoring Board was an organizational response to G20 criticisms (Botzem 2012). However, for us, the constituency of the Monitoring Board, consisting of capital market authorities, securities regulators and includes IOSCO and the European Commission, may delimit the 'public' in the public interest (IFRSF 2016). Botzem (2012, 109-110) argues that this is technocratic:

... the Monitoring Board was an attempt to square the circle: The IASB wants to react to its critics without making any substantial changes to its structure and by leaving 'technical' decision making untouched ... the key component in this mode of technocracy ... is the power to define what is to be considered relevant expertise

Thus, as a defense of the technocratic, Articulation D reconstitutes the public interest.

Thus, as we now have four competing articulations and six tropes for the 'public interest', we focus on explaining what these competing articulations $d o$ for the IASB.

\section{Analyzing the Rhetorical Redescriptions}

These four articulations redescribe the significance of the 'public interest' (Howarth and Griggs 2006, 29). This section, with careful interpretation, illustrates the impact of each 'redescription':

a) The 2010 and 2014 Mission confirms a relationship between quality accounting standards and the public interest, presenting the 'public interest' as an umbrella concept. However, this is constrained by a focus on developing standards, which ignores the outcomes of standard-setting (Burkhead and Miner 1971). Thus, the Mission statements demonstrate a consistent focus on procedural due process.

b) Articulation B redescribes the public interest, by suggesting that the public interest is discharged through due process. This rhetorically re-weights the public interest, technocratically, in two ways:

i) The role of the public interest is diminished in this articulation, as the Mission statements committed to developing IFRS in the 'public interest'. Articulation is not concerned with the standards, but redescribes the public interest as being served by following due process procedures. This means the public interest is relevant only to procedure (Bozeman 2007) with the 
effect that following due process procedures now amounts to serving the public interest.

ii) This redescription normatively revalues the public interest, as it is dischargeable through following due process procedures. The mission discusses developing high-quality standards, but this articulation limits 'quality' and the 'public interest' to the due process framework.

The effect of Articulation B is to position procedural due process as a technocratic proxy for the public interest, with the impact of devaluing the term. This renders the 'public interest' easier for the IASB to demonstrate by committing to process.

c) Articulation C's three tropes complicate what the 'public interest' does for the IASB:

i) In Trope 1, the IASB is 'motivated by ... the public interest'. This renames the concept. The Mission Statement commits to developing standards in the public interest, but this constrains the IASB, as the public interest is only a motivating factor. The impact is to rename the public interest as aspirational (rather than a commitment).

ii) Trope 2 conflicts with Trope 1 , as it revalues the normativity of the public interest. Trope 1 introduces 'motivation', but Trope 2 changes this to 'emphasize[s] that IFRS Standards are created to serve the public interest'. This differs equally to the Mission, which emphasized developing standards in the public interest. The impact of this is to shift the public interest from procedural to substantive due process (Horwitz 1989), and potentially, could constitutes historical revision given the GFC legitimacy-crisis (G20 2009), especially as Trope 2 claims this was the aim from the IASBs inception.

iii) However, at the same time, Trope 2 links the public interest to the financial markets, as 'market' limits stakeholders to interested parties including regulatory bodies, investors, preparers, stock markets and similar. ${ }^{8}$ Therefore, this delimits the 'public'. This movement re-weights the public interest from due process to an outcome focus measured against transparency (comparability and quality); accountability (reduced information gap) and economic efficiency (opportunities and risk, reduced cost). This narrow economic lens constrains the 'public interest' to special interests (Catlett 1960), reflecting Bezemer's (2010) reading of economic interests evident in the GFC.

iv) Trope 3, also outcome-focused, re-describes the public interest to trust, growth and long-term financial stability (which differs to the interests presented in Trope 2). This normatively revalues the concept by suggesting that trust, growth and long-term financial stability, as outcomes, result from 'public interest' regulation.

\footnotetext{
${ }^{8}$ These special interests should already be catered for by the Monitoring Board discussed above.
} 
v) Trope 3, introduces an important verb change: Trope 2 'serves' the public interest, but Trope 3 'fosters' the public interest. Fostering and serving are different concepts, and the impact is to assign a different cause (Skinner 2002, 183), while extending the signifiers attached to the public interest (Laclau 1996).

d) Articulation D presents a substantively different Mission from the 2001, 2010 and 2014 versions considered in this paper. This Mission re-focuses on procedural due process linking the 'public interest' to 'independent' governance structures and due process (IASB 2015, 1). The IASB draws an equivalence between 'public interest' and 'stakeholders', as a 'public interest organization' 'ensuring accountability to our stakeholders'. However, these are not synonyms in regulatory literature (Gallhofer and Haslam 2003, 2007). This attempt to revise the 'public' seems an (unconvincing) attempt to respond to the perception that special interests are captured the IASB (IFRSF $2015,1)$. However, this is unconvincing, due to the technocratic 'fostering [of] trust, growth and long-term financial stability', which adds confusion as these concepts are market constructs which has the effect of reflecting particular interests (Black 2002).

Given this analysis, we examine what these redescriptions do for the IASB, as the analysis demonstrates oscillation in the meaning of the public interest: from procedural due process (development) to substantive due process (service) to outcomes (fostering). ${ }^{9}$ These 'oscillations' (as a floating signifier) constitute rival, evaluative interpretations of the public interest (Howarth and Griggs 2006, 11). To structure our analysis of what the public interest does for the IASB, we draw on three literatures focusing on an ontological study of the impact of redescriptions:

a) The rhetorical strategy of organizational legitimacy (Suddaby and Greenwood 2005; Quack 2010);

b) The logic of 'ideological cover' (Howarth and Griggs 2006); and

c) The role of metaphor and metonyms as a floating signifier (Laclau and Mouffe 2001).

While the public interest acts as a floating signifier for the IASB, this has a broader impact concerning a politics of legitimacy and a politics of ideological cover. These impacts are interrelated, as depicting the 'public interest' as a floating signifier is central to the politics of

\footnotetext{
${ }^{9}$ See Figure 2 below
} 
legitimacy and ideological cover.

\section{Discussion}

\section{A rhetoric of sustaining organizational legitimacy}

The GFC pierced the IASB's technocratic veil by placing a spotlight on the political activities of accounting standard-setting (Botzem 2012, 2). Without this crisis, it is unlikely that the IASB would have paid such attention to the 'public interest' (Bengtsson 2011; Richardson and Eberlein 2011). Due to the crisis of legitimacy, the IASB had to do something and the rearticulation of the public interest constituted a response to the G20s political 'spotlight' as a mechanism for sustaining or regaining organizational (technocratic) legitimacy.

Suddaby and Greenwood $(2005,36)$ suggest that discourses acquire legitimacy through rhetoric. These discourses are negotiated and contingent. Botzem $(2012,153)$ argues:

This goes to show that the IASB today still holds onto the strategy adopted in the early 1980s of systematically involving actors considered instrumental in securing legitimacy for the IAS/IFRS with public authority ... The question of what independent interests of their own must be attributed to those international organizations cannot be answered based on this study ...

Thus, due to the spotlight of the GFC, the IASBs instrumentality in securing legitimacy is visible in how they reconstructed the public interest over a six-year period. This is the technocratic manner, where the preference is for the IASBs power to remain hidden (Suddaby and Greenwood 2005, 53; Hines 1988). This instrumentality, played out in a public interest discourse, involve 'communicative dynamics ... [that] emphasize the use of language to persuade constituencies of the desirability and appropriateness of the institutional deviance' (Suddaby and Greenwood 2005, 37).

Thus, the IASB responds to the legitimacy crisis in three ways:

a) By increasing communication about the public interest, this constitutes an attempt to regain organizational legitimacy (Quack 2010). The perceived effect is simply 
that the more the IASB discusses the concept, the more the IASB takes the public interest seriously (Suddaby and Greenwood 2005, 61). Brunsson (1989) highlights the difference between 'talk' and 'action', but in a technocratic regulatory space, the IASB hopes that 'talk' is perceived as 'action';

b) The competing public interest tropes illustrate internal instability in the IASB's institutional logics. The oscillation between procedural and substantive due process and outcomes illustrates contradictions over how the IASB understands the public interest (Quack 2010). Suddaby and Greenwood $(2005,62)$ suggest that the analysis of public debate is a window on internal tensions and contradictions.

c) The IASB's responses seek to re-establish organizational legitimacy as a technocracy (Jennings 2011; Laarson 2013; Shaw et al. 2015). As Quack (2010, 10) articulates for the construction of legitimacy:

\begin{abstract}
An argument frequently used by both private transnational governance schemes and international organizations is that they possess the necessary expertise to provide effective problem solutions. This expertise is often of a specialized and technical character, and its claimed superiority is difficult to assess for outsiders, not least because the borderlines between the pursuit of commercial self-interest and the provision of expertise are often blurred.
\end{abstract}

The response to the 'crisis' involved the new Monitoring Board and multiple articulations of the public interest. Botzem $(2012,110)$ argues, '[t]he IASB wants to react to its critics ... by leaving 'technical' decision making untouched'. The G20s critique recognized the technocratic expertise, by asking them to do it better. Thus, the IASB further emphasizes expertise, through a pragmatic, self-interested construction of legitimacy. Lazzarato $(2013,30)$ suggests that post-GFC, there has been a 'recourse to technocratic governments'.

Technocracy, itself, is rhetorical and the IASB claims that the whole organization is a 'steward of the public interest' (Botzem 2012, 153). Thus, the technocratic response to the crisis (for maintaining legitimacy) is to employ a language of change (employing rival tropes for the public interest) and introducing a Monitoring Board (whose constitution is made up of special, market interests). Technocratically, this amounts to "saying much and doing little" (Brunsson 1989): as Botzem $(2012,110)$ suggests, this is 'an especially important means of securing the position of experts in the field of accounting...'

In short, the public interest discussion is about visibility, as the IASB and IFRSF had to be seen to do something (Brunsson 1989; D. Carter 2008, 297; Black 2008). However, this is typical of technocratic expertise: Quack (2010) criticizes technocratic transnational governance arguing that such expertise operates to exclude the public from participating (which appears the case with the IASB). For Black (2008), this results in 'public interest' organizations serving special interests. This self-interested rhetorical legitimation results in a lack of clarity on who 
the public is and who the IASB are accountable to, but is used rhetorically to provide moral and political justification (Quack 2010, 13):

... transnational governance institutions use normative arguments about inclusiveness, expertise-based effectiveness and procedural legitimacy in various mixes to substantiate their legitimacy claims towards specific audiences and publics and to distinguish their own claims positively from those of competitors.

We argue that the IASB, through the 'public interest', construct legitimacy based on inclusivity, fairness and representation, while functioning technocratic expertise in such a manner as to exclude the public and focus on special market-based interests. The competing tropes illustrate a fundamental instability in the IASBs conception of the public interest, but as a response post-GFC, they constitute attempts at re-instituting their (technocratic) legitimacy.

These responses, we argue, also constitute a form of ideological cover, so with respect to organizational legitimacy, the next section considers the displacement effect from invoking multiple articulations of the public interest.

\section{The rhetoric of ideological cover}

The proliferation of public interest tropes by the IASB operates, ideologically, as a form of displacement (Howarth and Griggs 2006, 27). Each articulation of the public interest corresponds to a criticism of the IASB post-GFC. This has the effect of placing the IASB at the center of the legitimacy crisis and the IASB sought organizational legitimacy through ideological cover. Howarth and Griggs $(2006,27)$ argue why displacement is a political strategy:

... a strategy of displacing the existing terrain of argumentation, while simultaneously structuring the space of argumentation in a different way so as to display your arguments in the best possible light, offers the prospect of weakening the opposition, and strengthening one's own.

Thus, we argue that the IASB's rhetorical redescriptions of the public interest operate as ideological cover by displacing criticisms that emerged post-GFC (Botzem 2014; Porter 2014; Erb and Pelger 2015). Each redescription operated to displace a criticism of the IASB: 
a) The G20 and commentators critiqued the IASB for its stakeholder engagement, and mandated 'improve[d] involvement of stakeholders, including prudential regulators and emerging markets' (Deloitte 2009; Botzem 2012, 2014). Consequently, in response, the IASB introduced institutional reform with the Monitoring Board and IFRSF trustees committing to act in the 'public interest'. These actions directly address perceptions concerning governance;

b) Critics identified problems with special interests, due process and transparency (Gallhofer and Haslam 2003; Erb and Pelger 2015). Thus, the IASB focused on improved due process procedures and the public interest. The objective here is that the perception of appropriate due procedures addresses the perceived special interest problem.

c) Critics challenged the IASB for the economic vulnerability 'caused' by accounting standards on capital markets (IFRS 2015, 1; Botzem 2012). Thus, in re-articulating a focus on desirable outcomes including transparency and accountability, as well as market-focused outcomes including economic efficiency, trust, growth and long-term financial stability, the IASB sought to quieten this discontent. The impact of this is to address critics concerned with instability and the short-term investment focus.

These rhetorical strategies, in an organizational legitimacy strategy, displace criticisms of the IASB and re-structure the debate by placing the IASB as the 'steward' of the public interest (Botzem 2012). The impact is three-fold: a) this redescribes the IASB as synonymous with the public interest; b) it constructs the IASB as a responsive listener, considerate of criticism and in control; and c) it secures and centers the position of the IASB as technocratic governors of accounting regulation (Lazzarato 2013; Botzem 2012). Crucially, each rhetorical statement displaces, but does nothing to alter the IASB's technocracy. This reflects Brunsson (1989), as talk (rhetoric) can be a way of coping (displacing) contradictory demands. However, this form of ideological cover is likely short-term in nature, as the underlying contingencies will reemerge as the limits of 'talk' are exposed by future accounting crisis. However, in the short term, the multiple articulations of the public interest act as a form of ideological cover, as it requires careful analysis to unpack the limits within the floating signifier: in the meantime, the IASBs technocracy continues (Brunsson 1989; Glynos, Klimecki and Willmott 2015). 
In response to the political disquiet post-GFC, the redescriptions of the public interest constitute an attempt by the IASB to rhetorically legitimate their transnational standard-setting position. Neoliberalism provides the foundation to this displacement strategy, through the fantasmatic imagery of connecting public interest to capital markets. This fantasy operates to 'cover over' the IASB as a technocracy, by depicting the IASB as acting in the public interest with 'best practice' due process (Glynos and Howarth 2007). The impact of the redescriptions turns the focus to the 'public interest', representing the IASB as responsive and reflexive. However, as the underpinning technocracy is not impacted, this allows the IASB to avoid, in the short term at least, further substantive questions concerning their role as a transnational private policy maker (Quack 2010; Brunsson 1989). Thus, in the critical period post-GFC the claim to meeting broader public interest offers the IASB ideological cover for their standard setting (Howarth and Griggs 2006).

Underpinning this conversation is that the IASB constructed the public interest as a floating signifier, and this final section allows us to consider the impact of metaphor and metonym as a politics of the undecidable.

\section{Undecidability in the public interest}

We argue that the IASBs displacement strategy to regain legitimacy, constitutes a form of undecidability (Wullweber 2015). Laclau and Mouffe $(2001,8)$ argue that '[d]emocracy is suspended in an undecidable game between metaphor and metonymy', and explain that the undecidable is politics. The undecidability emanates from the unfixity that comes from constructing the public interest as an oscillating floating signifier (see Figure 2 below).

Insert Figure 2 about here 
The competing public interest articulations oscillate between procedural and substantive due process and outcomes concentrated on the 'public interest' as a nodal point. For the IASB, the public interest operates as a 'mobile army of metaphors [and] metonymies' (Nietzsche 1964, 180). In effect, the 'public interest' is a 'privileged signifier or reference point...in a discourse that binds together a particular "chain of significance"" (Howarth, Norval, and Stavrakakis 2000, 8). Figure 2 illustrates that the IASB (2010-2015) constructed the public interest as a floating signifier to incorporate both metaphoric and metonymic rhetoric devices. Aristotle's [c. $335 \mathrm{BCE}$ ] examination of metaphor recognized the transfer of quality from one to another in constituting social meaning (Aristotle in Freese 1975). In analyzing the articulations, we identify examples of metaphors in the rival terms, such as the transfer of meaning in equating the public interest with transparency or trust or with presenting the public interest as motivating the IASB or IFRS serving or fostering the public interest. Equally though, there are metonymic examples, which work by contiguity rather than similarity: food on a dish leads to referring to food as a 'dish' (Aristotle in Freese 1975). Metonyms do not transfer quality (there is nothing 'dish-like' about food), but rather they operate to displace. In our analysis, the public interest operating as a floating signifier and new governance structures operate metonymically.

While this rhetorical process is a response to the critics of the IASB, we see this is a risky strategy. In particular, each competing articulatory response to a criticism renders each trope contingent: each new articulation of the 'public interest' illustrates and names the lack in other articulations. There is risk that this strategy becomes destabilizing and delegitimizing due to uncertainty. Talk with no action is likely to fail in seeking legitimation (Quack 2010; Brunsson 1989). In oscillating between three competing metonyms of the public interest (procedural due process, substantive due process and outcomes) and floating metaphorically between a range of 'qualities' that the IASB employs in each articulation, the impact is to construct the public 
interest as an inherently flexible trope, with the IASB at the center of its networked technocratic governance structure. For example, if a criticism emerged concerning special market interests, the IASB can oscillate between competing interpretations of the public interest to 'smooth' over the critique:

a) By invoking the procedural due process metonym and the metaphor of governance processes or due process, this combination responds by presenting IASB processes are open and accessible to all interests;

b) By invoking the metonym of substantive due process and the metaphor of independence, this responds by illustrating a focus on stakeholders; and

c) By invoking the metonym of outcomes and the metaphor of trust, this responds by constructing the IASB as being focused only on regulation for the public interest.

Thus, our analysis illustrates the impact of constructing the public interest as a floating signifier. This, for Laclau and Mouffe (2001, 112-113) is the politics of articulation:

The practice of articulation, therefore, consists in the construction of nodal points which partially fix meaning; ... [which] proceeds from the openness of the social, a result ... of the constant overflowing of every discourse by the infinitude of the field of discursivity.

The shadowy side of the political here is that every articulation of the public interest operates simultaneously to displace critique, but equally constitutes part of an undecidable game (Laclau and Mouffe 2001, 10). In discourse theory terms, the public interest trope means everything and nothing as a condition of the possible and the impossible (Torfing 2005, 20).

\section{Concluding Notes: The 'Public Interest' Challenge}

Thus, we illustrate a politics of the undecidable in the IASBs redescriptions of the public interest (2010-2015) in response to the legitimacy crisis post-GFC (Botzem 2012). In focusing on what this articulatory politics does for the IASB, we argue that this was a mechanism for: a) re-instituting organizational legitimacy in technocratic governance (through the monitoring board and commitments to due process) (Suddaby and Greenwood 2005; Quack 2010); b) seeking 'ideological cover' by centering the IASB in an interconnected regulatory network, 
with the effect of displacing critics through the public interest articulations (Griggs and Howarth 2006; Black 2008); and c) instituting a politics of undecidability within the public interest discourse (and accounting regulation) permitting the IASB to respond to crisis through combinations of metonym and metaphor (Laclau and Mouffe 2001).

The effect of this politics is to reinstitute the IASBs technocracy, as each competing articulation re-defines and delimits the public interest and its contingencies, which ultimately subverts the public interest. Competing articulations are 'disappointing', as for the technocratic IASB, constructing the public interest as a floating signifier will likely dispel discontent post-GFC in the short term, but we argue future legitimacy challenges will emerge due to the antagonisms caused by the floating signifier (Laclau 1996; Howarth 2013). Further, the IASB acts to displace three elements through their technocratic governance: they mask their focus on advanced financial capital and capital markets; they mask the politics of regulation through technocracy and they mask that they are non-democratic. Despite this, they continue to be supported by the G20, the World Bank and the IMF as transnational accounting policy makers. For us, this illustrates the role of networked regulatory policy making and the challenges of drawing on democratic imageries without obvious constituencies (Quack 2010; Black 2008) The consequences of this for the IASB, for advanced financial capital and neoliberalism requires further exploration (Lazzarato 2012). The political act here is to buy time in the face of criticism from the G20 and other interested parties, heightened by the 'finger-pointing' postGFC. The political act then is to reinforce the technocratic power through extending the chains of equivalence in a hegemonic process of invoking democratic imageries of the public interest. It is coalition-building in the crude sense by attempting to please everybody. The impact of this approach is that the 'public interest' as a floating signifier covers over the contingency of the 'hidden power' of the IASB (Hines 1988), as an institutor and protector of a substantive shift 
towards financial capital as a driver of the financial crisis (Lazzarato 2012, 2013). This is an instance of much rhetorical posturing, where the underlying power structure, hidden as it might be, is reinforced through the redescription. 


\section{Empirical Documents}

Economic and Financial Affairs Council. 2006. Commission Services Working Paper on Governance Developments in the IASB and IASCF.

http://ec.europa.eu/internal_market/accounting/docs/ias/iasb_governance_report_workin g_paper_en.pdf

IASB. 2001. Mission Statement. London: IFRS Foundation

IASB. 2006. International Financial Reporting Standards, including International Accounting Standards and Interpretations. London: IASCF.

IASB. 2017. "How we are structured". http://www.ifrs.org/About-us/Pages/How-we-arestructured.aspx

IASB. 2010. How we consult. London: IFRS Foundation http://www.ifrs.org/Documents/HOWWECONSULTFINALvb.pdf

IASB. 2015. Who We Are and What We Do. London: IFRS Foundation. http://www.ifrs.org/Theorganisation/Documents/2015/WhoWeAre_ENGLISH_July\%202015.pdf

IFRS Foundation. 2013. Due Process Handbook: Feedback Statement. London: IFRS Foundation.

http://www.ifrs.org/DPOC/Documents/2013/Due_Process_Handbook_Resupply_28_Feb _2013_WEBSITE.pdf

IFRS Foundation. 2014 The Organization: About the IFRS Foundation and the IASB. http://www.ifrs.org/The-organisation/Pages/IFRS-Foundation-and-the-IASB.aspx

IFRS Foundation. 2015. Working in the Public Interest: The IFRS Foundation and the IASB. London: IFRS Foundation. http://www.ifrs.org/About-us/Documents/Working-in-thePublic-Interest.pdf.

IFRS Foundation. 2016. The Monitoring Board. London: IFRS Foundation. http://www.ifrs.org/about-us/pages/Monitoring-Board.aspx

\section{References}

Aristotle, c. 335 BCE, The Art of Rhetoric, trans by Freese, J.H. 1975. London: Harvard University Press.

Bengtsson, E. 2011. "Repoliticalization of Accounting Standard Setting-The IASB, the EU and the Global Financial Crisis". Critical Perspectives on Accounting, 22(6), 567-580.

Bezemer, D. J. (2010). "Understanding Financial Crisis through Accounting Models. Accounting, Organizations and Society, 35(7), 676-688.

Black, J. 2002. “Critical Reflections on Regulation”. Australian Journal of Legal Philosophy, 27(1), 1-35.

Black, J. 2008. "Constructing and Contesting Legitimacy and Accountability in Polycentric Regulatory Regimes”. Regulation \& Governance, 2(2), 137-164.

Botzem, S. 2012. The Politics of Accounting Regulation: Organizing Transnational Standard Setting in Financial Reporting. Cheltenham: Edward Elgar Publishing. 
Botzem, S. 2014. "Transnational Standard Setting in Accounting: Organizing Expertise-Based Self-Regulation in Times of Crises". Accounting, Auditing and Accountability Journal, 27(6), 933-955.

Botzem, S., and Hofmann, J. 2010. "Transnational Governance Spirals: The Transformation of Rule-Making Authority in Internet Regulation and Corporate Financial Reporting”. Critical Policy Studies, 4(1), 18-37.

Botzem, S., and Quack, S. 2009. “(No) limits to Anglo-American Accounting? Reconstructing the History of the International Accounting Standards Committee: A Review Article". Accounting, Organizations and Society, 34(8), 988-998.

Bozeman, B. 2007. Public Values and Public Interest: Counterbalancing Economic Individualism. Washington DC: Georgetown University Press.

Brunsson, N. 1989. The Organization of Hypocrisy: Talk, Decisions and Actions in Organizations. Chichester: John Wiley \& Sons.

Burkhead, J., and Miner, J. 1971. Public Expenditure. Chicago: Aldine-Atherton.

Camfferman, K., and Zeff, S. A. 2007. Financial Reporting and Global Capital Markets: A History of the International Accounting Standards Committee, 1973-2000. Oxford: Oxford University Press.

Carter, D. B. 2008. Crossing the Wires: The Interface between Law and Accounting and the Discourse Theory Potential of Telecommunications Regulation. Ph.D. Diss. Victoria University of Wellington.

Carter, P. 2011. “Governing Welfare Reform Symbolically: Evidence Based or Iconic Policy?” Critical Policy Studies, 5(3), 247-263.

Catlett, G. R. 1960. "Factors that Influence Accounting Principles". Journal of Accountancy, (Oct 1960), 44-50.

Chiapello, E. 2007. "Accounting and the Birth of the Notion of Capitalism". Critical Perspectives on Accounting, 18(3), 263-296.

Chiapello, E., and Medjad, K. 2009. "An Unprecedented Privatisation of Mandatory StandardSetting: The Case of European Accounting Policy". Critical Perspectives on Accounting, 20(4), 448-468.

Cooper, C. 2015. "Accounting for the Fictitious: A Marxist Contribution to Understanding Accounting's Roles in the Financial Crisis". Critical Perspectives on Accounting, 30, 6382.

Cortese, C. L., Irvine, H. J., and Kaidonis, M. A. 2010. "Powerful Players: How Constituents Captured the Setting of IFRS 6: An Accounting Standard for the Extractive Industries". Accounting Forum, 34(2), 76-88.

Czarniawska, B. 2000. "The Uses of Narrative in Organization Research. GRI Report. https://gupea.ub.gu.se/handle/2077/2997.

Deegan, C., and Unerman, J. 2011. Financial Accounting Theory. Maidenhead: McGraw Hill.

Dellaportas, S., and Davenport, L. 2008. "Reflections on the Public Interest in Accounting". Critical Perspectives on Accounting, 19(7), 1080-1098.

Deloitte. 2009. G20 Declaration and IASB Response. London: IAS Plus. https://www.iasplus.com/en/news/2009/April/news4621 
Derrida, J. 1988. Limited Inc. Weber, S., and Mehlman, J. (trans.). Illinois: Northwestern University Press.

Devenney, M. 2002. "Critical theory and Democracy". In A. Finlayson and J. Valentine (Eds). Politics and post-structuralism: An introduction. Edinburgh: Edinburgh University Press.

Erb, C., and Pelger, C. 2015. "“Twisting words"? A Study of the Construction and Reconstruction of Reliability in Financial Reporting Standard-Setting". Accounting, Organizations and Society, 40(1), 13-40.

Frezatti, F., Carter, D. B., and Barroso, M. 2014. "Accounting without Accounting; Informational Proxies and the Construction of Organisational Discourses". Accounting, Auditing and Accountability Journal, 27(3), 426-464.

G20. 2009. Declaration on Strengthening the Financial System, London Summit. http://www.g20.utoronto.ca/2009/2009ifi.pdf.

Gaffikin, M. 2007. "Accounting Research and Theory: The Age of Neo-Empiricism". Australasian Accounting Business \& Finance Journal, 1(1), 1-19.

Gaffikin, M. 2008. Accounting Theory: Research, Regulation and Accounting Practice. Frenchs' Forest: Pearson Education.

Gallhofer, S., and Haslam, J. 2003. Accounting and Emancipation: Some Critical Interventions. London: Routledge.

Gallhofer, S., and Haslam, J. 2007. "Exploring Social, Political and Economic Dimensions of Accounting in the Global Context: The International Accounting Standards Board and Accounting Disaggregation". Socio-Economic Review, 5(4), 633-664.

Gerboth, D. L. 1973. "Research, Intuition and Politics in Accounting Inquiry". Accounting Review, 48(3), 475-482.

Gill, M. 2009. Accountants' Truth: Knowledge and Ethics in the Financial World. New York: Oxford University Press.

Glynos, J., and Howarth, D. 2007. Logics of Critical Explanation in Social and Political Theory. New York: Routledge.

Glynos, J., Klimecki, R., and Willmott, H. 2015. "Logics in Policy and Practice: A Critical Nodal Analysis of the UK Banking Reform Process". Critical Policy Studies, 9(4), 393415 .

Green, M. 2007. "Delivering Discourse: Some Ethnographic Reflections on the Practice of Policy Making in International Development”. Critical Policy Studies, 1(2), 139-153.

Griggs, S. and Howarth, D. 2013. The Politics of Airport Expansion in the United Kingdom: Hegemony, Policy and the Rhetoric of Sustainable Aviation. Manchester: Manchester University Press.

Henry, N. 2015. Public Administration and Public Affairs. New York: Routledge.

Hines, R. D. 1988. "Financial Accounting: In Communicating Reality, We Construct Reality". Accounting, Organizations and Society, 13(3), 251-261.

Hines, R.D. 1991. “The FASB's Conceptual Framework, Financial Accounting and the Maintenance of the Social World". Accounting, Organizations and Society, 16(4), 313331. 
Horwitz, R. B. 1989. The Irony of Regulatory Reform: The Deregulation of American Telecommunications. New York: Oxford University Press.

Howarth, D. 2013. Poststructuralism and After: Structure, Subjectivity and Power. Hampshire: Palgrave Macmillan.

Howarth, D. and Griggs, S. 2006. "Metaphor, Catachresis and Equivalence: The Rhetoric of Freedom to Fly in the Struggle over Aviation Policy in the United Kingdom". Policy and Society, 25(2), 23-46.

Howarth, D., Glynos, J., and Griggs, S. 2016. "Discourse, Explanation and Critique". Critical Policy Studies, 10(1), 99-104.

Howarth, D., Norval, A., and Stavrakakis, Y. 2000. Discourse Theory and Political Analysis: Identities, Hegemonies and Social Change. Manchester: Manchester University Press.

Jennings, B. 2011. "Poets of the Common Good: Experts, Citizens, Public Policy". Critical Policy Studies, 5(3), 334-339.

Larsson, O. L. 2013. "Sovereign Power Beyond the State: A Critical Reappraisal of Governance by Networks". Critical Policy Studies, 7(2), 99-114.

Laclau, E., and Mouffe C. 2001. Hegemony and Socialist Strategy: Towards a Radical Democratic Politics. London: Verso.

Laclau, E. 1996. Emancipation(s). London: Verso.

Lazzarato, M. 2012. The Making of the Indebted Man: An Essay on the Neoliberal Condition. Amsterdam: Semiotext(e).

Lazzarato, M. 2013. Governing by Debt. Pasadena: Semiotext(e).

Lövbrand, E., and Stripple, J. 2011. "Making Climate Change Governable: Accounting for Carbon as Sinks, Credits and Personal Budgets". Critical Policy Studies, 5(2), 187-200.

Messner, M. 2009. "The Limits of Accountability". Accounting, Organizations and Society, 34(8), 918-938.

Mitchell, A., Sikka, P., Puxty, T. and Willmott, H. 1994. "Ethical Statements as Smokescreens for Sectional Interests: The Case of the UK Accountancy Profession". Journal of Business Ethics, 13, 39-51.

Modell, S. 2017. "Critical Realist Accounting Research: In Search of its Emancipatory Potential”. Critical Perspectives on Accounting, 42, 20-35

Mol, A., and Law, J. 2004. "Embodied Action, Enacted Bodies: The Example of Hypoglycaemia”. Body and Society, 10(2-3), 43-62.

Morgan, G. 1988. "Accounting as Reality Construction: Towards a New Epistemology for Accounting Practice”. Accounting, Organizations and Society, 13(5), 477-485.

Nietzsche, F. 1964. [1873] "On Truth and Falsity in an Extramoral Sense". Trans. By Mugge, M. In Levy, O. (Ed.) The Complete Works of Friedrich Nietzsche (Vol. 2). New York: Russell \& Russell.

Pautz, H. 2016. "Managing the Crisis? Think-Tanks and the British Response to Global Financial Crisis and Great Recession”. Critical Policy Studies, 11(2), 191-210

Pacter, P. 2015. IFRS as Global Standards: A Pocket Guide. London: IFRS Foundation.

Pelger, C., and Spieß, N. 2017. “On the IASB's Construction of Legitimacy - The Case of the 
Agenda Consultation Project”. Accounting and Business Research, 47(1), 64-90.

Peltzman, S. 1976. "Toward a more General Theory of Regulation". Journal of Law and Economics, 19(2), 211-240.

Porter, T. 2014. Transnational Financial Regulation After the Crisis. London: Routledge.

Posner, R. A. 1974. "Theories of Economic Regulation". Bell Journal of Economics and Management Science, 5, 335-358.

Quack, S. 2010. "Law, Expertise and Legitimacy in Transnational Economic Governance: An Introduction”. Socio-Economic Review, 8(1), 3-16

Quintilian, M.F. 1920. Institutio Oratoria. Butler, H.E. (trans.), Loeb Classical Library, Cambridge: Harvard University Press.

Richardson, A. J. and Eberlein, B. 2011. "Legitimating Transnational Standard-Setting: The Case of the International Accounting Standards Board". Journal of Business Ethics, 98(2), 217-245.

Sayer, D. 1979. Marx's Method: Ideology, Science, and Critique in Capital. Hassocks: Harvester Press.

Sayre, W. S. 1958. "Premises of Public Administration: Past and Emerging". Public Administration Review, 18(2), 102-105.

Scherrer, C. 2011. "Reproducing Hegemony: US Finance Capital and the 2008 Crisis". Critical Policy Studies, 5(3), 219-246.

Shaw, S. E., Russell, J., Parsons, W., Greenhalgh, T. 2015. "The View from Nowhere? How Think Tanks Work to Shape Health Policy”. Critical Policy Studies, 9(1), 58-77.

Skinner, Q. 2002. Visions of Politics (Vol. 2). Cambridge: Cambridge University Press.

Suddaby, R., and Greenwood, R. 2005. "Rhetorical Strategies of Legitimacy". Administrative Science Quarterly, 50, 35-67.

Torfing, J. 2005. "Discourse Theory: Achievements, Arguments and Challenges. In Howarth, D., Torfing, J. (Eds.), Discourse Theory in European Politics. London: Palgrave.

Wagenaar, H. 2012. "Dwellers on the Threshold of Practice: The Interpretivism of Bevir and Rhodes". Critical Policy Studies, 6(1), 85-99.

Wingard, C., Bosman, J., and Amisi, B. 2016. "The Legitimacy of IFRS: An Assessment of the Influences on the Due Process of Standard-Setting". Meditari Accountancy Research, 24(1), 134-156.

Wolcher, L. E. 2007. "Senseless Kindness: The Politics of Cost-Benefit Analysis". Law and Inequality, 25, 147-202.

Wullweber, J. 2015. "Global Politics and Empty Signifiers: The Political Construction of High Technology”. Critical Policy Studies, 9(1), 78-96. 


\section{How we are structured}

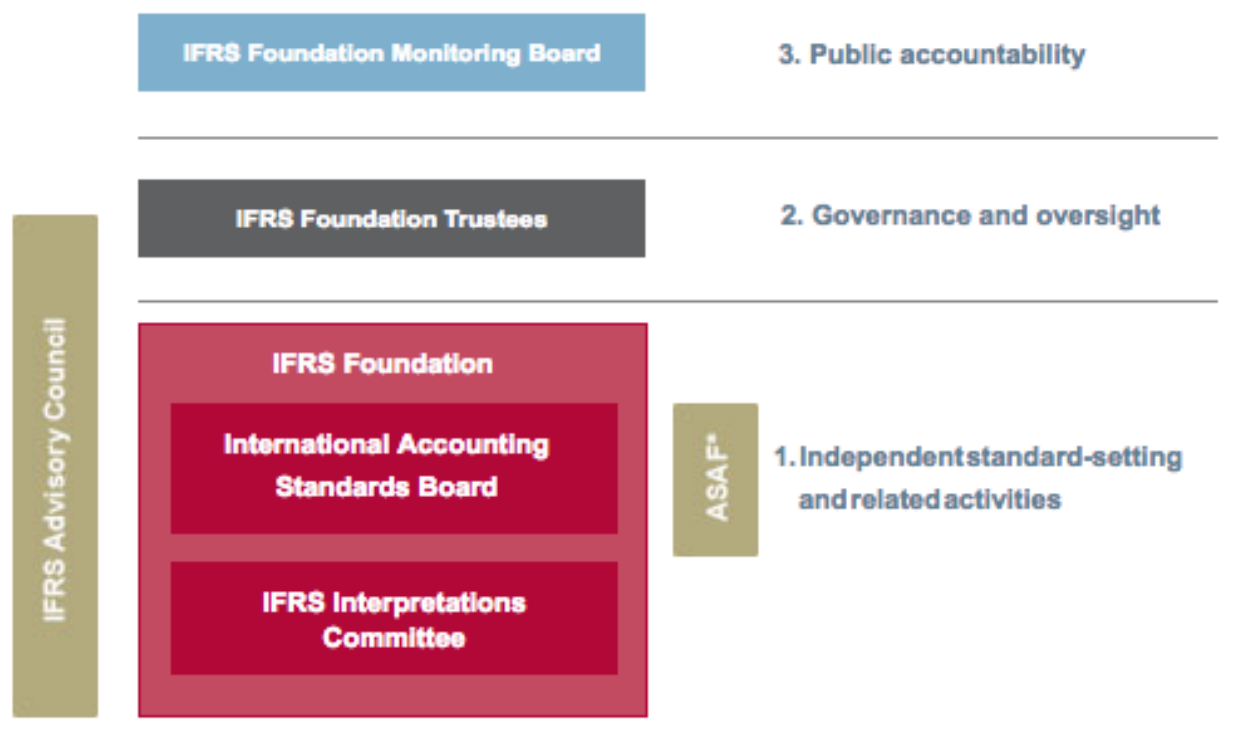

•Accounting Standards Advisory Forum (representatives of the international standard-setting community)

(IASB, 2017: 1) 
We present two elements here.

The first constitutes the document archive for the paper. This constitutes all the documents published within the IASB and IFRSF concerning the public interest. All these documents were publicly available and are or were the documents available in the period 2010-2015.

The second is the list of documents including the phrase 'the public interest' before 2010 publicly available from the IASB and IFRSF.

This is to illustrate the scale of increase and the shift to alternative types of the public interest. Second, this is to illustrate that we have a vast array of documents supporting the tropes analyzed.

Public Interest Documents: 2010-2015

\begin{tabular}{|c|c|c|c|}
\hline Document title and link & Author & $\begin{array}{l}\text { Public } \\
\text { Interest } \\
\text { Type }\end{array}$ & Year \\
\hline $\begin{array}{l}\text { How does the IASB work in the public interest? } \\
\text { http://www.ifrs.org/Features/Pages/How-does-the-IASB-work-in- } \\
\text { the-public-interest.aspxhttp://www.ifrs.org/Features/Pages/How- } \\
\text { does-the-IASB-work-in-the-public-interest.aspx }\end{array}$ & IFRSF and IASB & $\begin{array}{l}\text { Procedural due } \\
\text { process } \\
\text { Substantive } \\
\text { due process } \\
\text { Outcomes }\end{array}$ & 2015 \\
\hline $\begin{array}{l}\text { IASB Chairman presents new mission statement } \\
\text { http://www.ifrs.org/Alerts/Conference/Pages/IASB-Chairman- } \\
\text { presents-new-mission-statement-April-2015.aspx }\end{array}$ & $\begin{array}{l}\text { IASB } \\
\text { Hans } \\
\text { Hoogervorst }\end{array}$ & Outcomes & 2015 \\
\hline $\begin{array}{l}\text { A } 2015 \text { IFRSF publication, entitled, Working in the Public Interest: } \\
\text { The IFRSF and the IASB }\end{array}$ & IFRSF and IASB & $\begin{array}{l}\text { Procedural due } \\
\text { process } \\
\text { Substantive } \\
\text { due process } \\
\text { Outcomes }\end{array}$ & 2015 \\
\hline $\begin{array}{l}\text { IFRSF } \quad \text { Trustees: } \quad \text { http://www.ifrs.org/About-us/IFRS- } \\
\text { Foundation/Careers/Pages/Trustees.aspx }\end{array}$ & IFRSF & $\begin{array}{l}\text { Procedural due } \\
\text { process }\end{array}$ & 2015 \\
\hline $\begin{array}{l}\text { The global reach of IFRS is expanding } \\
\text { http://www.ifrs.org/Features/Pages/Global-reach-of-IFRS-is- } \\
\text { expanding.aspxhttp://www.ifrs.org/Features/Pages/Global-reach- } \\
\text { of-IFRS-is-expanding.aspx }\end{array}$ & $\begin{array}{l}\text { Paul Pacter- } \\
\text { former member of } \\
\text { the IASB }\end{array}$ & Outcomes & 2015 \\
\hline A 2015 IASB Mission Statement & IFRSF and IASB & $\begin{array}{l}\text { Procedural due } \\
\text { process } \\
\text { Outcomes }\end{array}$ & 2015 \\
\hline IASB Mission Statement 2014 & IASB & $\begin{array}{l}\text { Procedural due } \\
\text { process }\end{array}$ & 2014 \\
\hline $\begin{array}{l}\text { Investors in Financial Reporting programme } \\
\text { http://www.ifrs.org/Features/Pages/IASB-launches-Investors-in- } \\
\text { Financial-Reporting-programme-December-2014.aspx }\end{array}$ & IFRSF & $\begin{array}{l}\text { Substantive } \\
\text { due process }\end{array}$ & 2014 \\
\hline
\end{tabular}




\begin{tabular}{|c|c|c|c|}
\hline $\begin{array}{l}\text { Trustees welcome renewal of Europe's financial contribution 2014- } \\
2020 \text { to the global funding of the IFRSF } \\
\text { http://www.ifrs.org/Alerts/Governance/Pages/Trustees-welcome- } \\
\text { renewal-of-Europe-financial-contribution-March-2014.aspx }\end{array}$ & Trustees & $\begin{array}{l}\text { Procedural due } \\
\text { process }\end{array}$ & 2014 \\
\hline $\begin{array}{l}\text { Investors in Financial Reporting Programme launch } \\
\text { http://www.ifrs.org/Investors-in-Financial- } \\
\text { Reporting/Documents/IASB-investor-programme-PR-December- } \\
\text { 2014.pdf }\end{array}$ & IASB & $\begin{array}{l}\begin{array}{l}\text { Procedural due } \\
\text { process, }\end{array} \\
\text { Substantive } \\
\text { due process } \\
\text { Outcomes }\end{array}$ & 2014 \\
\hline $\begin{array}{l}\text { Constructive Cooperation for International Standards } \\
\text { http://www.ifrs.org/Alerts/PressRelease/Pages/Constructive- } \\
\text { Cooperation-for-International-Standards-May-2013.aspx }\end{array}$ & IASB and IFAC & $\begin{array}{l}\text { Outcomes } \\
\text { Procedural due } \\
\text { process }\end{array}$ & 2013 \\
\hline $\begin{array}{l}\text { Progress towards global adoption of IFRS } \\
\text { http://www.ifrs.org/Alerts/PressRelease/Pages/IFRS-Foundation- } \\
\text { charts-progress-towards-global-adoption-of-IFRS-June-2013.aspx } \\
\end{array}$ & IFRSF & Outcomes & 2013 \\
\hline $\begin{array}{l}\text { IFRSF seeks candidates to fill Trusteeship vacancies } \\
\text { http://www.ifrs.org/Alerts/Governance/Pages/Invitation-for- } \\
\text { Trustee-vacancies.aspx }\end{array}$ & IFRSF & $\begin{array}{l}\text { Procedural due } \\
\text { process }\end{array}$ & 2013 \\
\hline $\begin{array}{l}\text { Public forum to discuss disclosure overload } \\
\text { http://www.ifrs.org/Alerts/PressRelease/Documents/2012/PR- } \\
\text { disclosure-forum- } \\
\text { 121112.pdfhttp://www.ifrs.org/Alerts/PressRelease/Documents/20 } \\
\text { 12/PR-disclosure-forum-121112.pdf }\end{array}$ & IASB & $\begin{array}{l}\text { Procedural due } \\
\text { process }\end{array}$ & 2012 \\
\hline Due Process Handbook: IASB & IFRSF and IASB & $\begin{array}{l}\text { Procedural due } \\
\text { process }\end{array}$ & 2012 \\
\hline $\begin{array}{l}\text { Due process oversight } \\
\text { http://www.ifrs.org/Features/Pages/Due-process-oversight.aspx }\end{array}$ & Robert Bruce & $\begin{array}{l}\text { Substantive } \\
\text { due process }\end{array}$ & 2011 \\
\hline $\begin{array}{l}\text { Conclusions of the March } 2011 \text { Trustees' meeting, London } \\
\text { http://www.ifrs.org/News/Announcements-and- } \\
\text { speeches/Pages/March-2011-Trustees-meeting.aspx }\end{array}$ & IFRSF Trustees & $\begin{array}{l}\text { Procedural due } \\
\text { process }\end{array}$ & 2011 \\
\hline $\begin{array}{l}\text { Speech: 'China and IFRS - an opportunity for leadership in global } \\
\text { financial reporting' } \\
\text { http://www.ifrs.org/News/Announcements-and- } \\
\text { Speeches/Pages/Hans-Hoogervorst-Beijing-speech-July-2011.aspx }\end{array}$ & $\begin{array}{l}\text { Hans-Hoogervorst } \\
\text { and IFRSF }\end{array}$ & $\begin{array}{l}\text { Substantive } \\
\text { due process } \\
\text { Outcomes }\end{array}$ & 2011 \\
\hline $\begin{array}{l}\text { Welcome from the incoming Chairman of the IASB } \\
\text { http://www.ifrs.org/Features/Documents/HansJuly2011.pdfhttp://w } \\
\text { ww.ifrs.org/Features/Documents/HansJuly2011.pdf }\end{array}$ & Hans Hoogervorst & $\begin{array}{l}\text { Substantive } \\
\text { due process }\end{array}$ & 2011 \\
\hline IASB Mission Statement 2010 & IASB & $\begin{array}{l}\text { Procedural due } \\
\text { process }\end{array}$ & 2010 \\
\hline
\end{tabular}




\begin{tabular}{|c|c|c|c|}
\hline $\begin{array}{l}\text { Financial Crisis Advisory Group letter to G-20 on IASB and FASB } \\
\text { progress } \\
\text { http://www.ifrs.org/News/Announcements-and- } \\
\text { Speeches/Pages/FCAG-Issues-Letter-to-G-20.aspx }\end{array}$ & $\begin{array}{lr}\text { Harvey } & \mathrm{J} . \\
\text { Goldschmid } & \text { and } \\
\text { Hans Hoogervorst }\end{array}$ & $\begin{array}{l}\text { Procedural due } \\
\text { process }\end{array}$ & 2010 \\
\hline $\begin{array}{l}\text { Accounting Standards Advisory Forum (ASAF) } \\
\text { http://www.ifrs.org/About-us/IASB/Advisory-- } \\
\text { bodies/ASAF/Pages/Accounting-Standards-Advisory- } \\
\text { Forum.aspxhttp://www.ifrs.org/About-us/IASB/Advisory- } \\
\text { bodies/ASAF/Pages/Accounting-Standards-Advisory-Forum.aspx }\end{array}$ & IFRSF & $\begin{array}{l}\text { Procedural due } \\
\text { process }\end{array}$ & $\begin{array}{l}\text { No } \\
\text { Date }\end{array}$ \\
\hline $\begin{array}{l}\text { The IASB Investors in Financial Reporting programme } \\
\text { http://www.ifrs.org/Investors-in-Financial-Reporting }\end{array}$ & IASB & Outcomes & $\begin{array}{l}\text { No } \\
\text { date }\end{array}$ \\
\hline $\begin{array}{l}\text { Speaking engagements } \\
\text { http://www.ifrs.org/The-organisation/Speaking-engagements }\end{array}$ & IFRSF & Outcomes & $\begin{array}{l}\text { No } \\
\text { Date }\end{array}$ \\
\hline $\begin{array}{l}\text { What are IFRS? } \\
\text { http://www.ifrs.org/About-us/Pages/What-are-IFRS.aspx }\end{array}$ & IASB and IFRSF & $\begin{array}{l}\text { Substantive } \\
\text { due process }\end{array}$ & $\begin{array}{l}\text { No } \\
\text { date }\end{array}$ \\
\hline $\begin{array}{l}\text { ASAF webpage } \\
\text { http://www.ifrs.org/About-us/IASB/Advisory- } \\
\text { bodies/ASAF/Pages/Accounting-Standards-Advisory-Forum.aspx }\end{array}$ & $\begin{array}{l}\text { IASB and } \\
\text { Accounting } \\
\text { Standards } \\
\text { Advisory Forum } \\
\text { (ASAF) }\end{array}$ & $\begin{array}{l}\text { Procedural due } \\
\text { process } \\
\text { Outcomes }\end{array}$ & $\begin{array}{l}\text { No } \\
\text { date }\end{array}$ \\
\hline $\begin{array}{l}\text { Governance and Accountability } \\
\text { http://www.ifrs.org/The-organisation/Governance-and- } \\
\text { accountability }\end{array}$ & IFRSF and IASB & $\begin{array}{l}\text { Substantive } \\
\text { due process }\end{array}$ & $\begin{array}{l}\text { No } \\
\text { Date }\end{array}$ \\
\hline $\begin{array}{l}\text { IFRS Foundation Policies } \\
\text { http://www.ifrs.org/The-organisation/Governance-and- } \\
\text { accountability/IASC-Foundation-Policies }\end{array}$ & IFRSF and IASB & Outcomes & $\begin{array}{l}\text { No } \\
\text { Date }\end{array}$ \\
\hline $\begin{array}{l}\text { Working relationships with local standard -setters } \\
\text { http://www.ifrs.org/Use-around-the-world/Pages/Working- } \\
\text { relationships-with-local-standard-setters.aspx }\end{array}$ & IFRSF & $\begin{array}{l}\text { Procedural due } \\
\text { process }\end{array}$ & $\begin{array}{l}\text { No } \\
\text { Date }\end{array}$ \\
\hline $\begin{array}{l}\text { Working with National standard-setters and Regional Bodies: } \\
\text { http://www.ifrs.org/Use-around-the-world/Pages/Regional-and- } \\
\text { national-standard-setting-bodies-.aspx }\end{array}$ & $\begin{array}{l}\text { IFRSF } \\
\text { Webpage }\end{array}$ & $\begin{array}{l}\text { Substantive } \\
\text { due process }\end{array}$ & $\begin{array}{l}\text { No } \\
\text { Date }\end{array}$ \\
\hline
\end{tabular}

Public Interest Documents Archived before 2010

\begin{tabular}{|l|l|l|l|}
\hline Document title and link & Author & $\begin{array}{l}\text { Public } \\
\text { Interest } \\
\text { Type }\end{array}$ & Year \\
\hline $\begin{array}{l}\text { Two successors for retiring Trustees } \\
\text { http://www.ifrs.org/News/Press-Releases/Pages/IASC-Foundation- } \\
\text { announces-two-successors-for-retiring-Trustees.aspx }\end{array}$ & IASC Foundation & $\begin{array}{l}\text { Procedural due } \\
\text { process }\end{array}$ & 2009 \\
\hline $\begin{array}{l}\text { IASB standards for 2007 } \\
\text { http://www.ifrs.org/News/Press-Releases/Pages/IASC-Foundation- } \\
\text { publishes-complete-IASB-standards-for-2007.aspx }\end{array}$ & $\begin{array}{l}\text { IASC Foundation } \\
\text { and IASB }\end{array}$ & $\begin{array}{l}\text { Procedural due } \\
\text { process }\end{array}$ & 2007 \\
\hline
\end{tabular}




\begin{tabular}{|c|c|c|c|}
\hline $\begin{array}{l}\text { Strategy to Enhance Governance - Report on Conclusions } \\
\text { http://www.ifrs.org/News/Press-Releases/Pages/Trustees- } \\
\text { Announce-Strategy-to-Enhance-Governance-Report-on- } \\
\text { Conclusions-at-Trustees-Meeting.aspx }\end{array}$ & IFRSF Trustees & $\begin{array}{l}\text { Procedural due } \\
\text { process }\end{array}$ & 2007 \\
\hline $\begin{array}{l}\text { Four Trustees reappointed - public search for new candidates } \\
\text { http://www.ifrs.org/News/Press-Releases/Pages/Four-Trustees- } \\
\text { reappointed-public-search-for-new-candidates.aspx }\end{array}$ & IASB & $\begin{array}{l}\text { Procedural due } \\
\text { process }\end{array}$ & 2007 \\
\hline $\begin{array}{l}\text { Steps to assist adoption of IFRSs and reinforce consultation: no } \\
\text { new standards until } 2009 \\
\text { http://www.ifrs.org/News/Press-Releases/Pages/IASB-takes-steps- } \\
\text { to-assist-adoption-of-IFRSs-and-reinforce-consultation-no-new- } \\
\text { standards-until-2009.aspx }\end{array}$ & IFRSF trustees & $\begin{array}{l}\text { Procedural due } \\
\text { process }\end{array}$ & 2007 \\
\hline $\begin{array}{l}\text { IFRS standards for } 2005 \\
\text { http://www.ifrs.org/Archive/Press-Relases- } \\
\text { Archive/2005/Pages/IASB-publishes-complete-standards-for- } \\
\text { 2005.aspx }\end{array}$ & IASB & $\begin{array}{l}\text { Procedural due } \\
\text { process }\end{array}$ & 2006 \\
\hline $\begin{array}{l}\text { Trustees approve constitutional changes } \\
\text { http://www.ifrs.org/Archive/Press-Relases- } \\
\text { Archive/2005/Pages/Trustees-approve-constitutional-changes.aspx }\end{array}$ & IASB & $\begin{array}{l}\text { Procedural due } \\
\text { process }\end{array}$ & 2005 \\
\hline $\begin{array}{l}\text { IASC Foundation Reappoints Three IASB Members } \\
\text { http://www.ifrs.org/Archive/Press-Relases- } \\
\text { Archive/2005/Pages/IASC-Foundation-Reappoints-Three-IASB- } \\
\text { Members.aspx }\end{array}$ & IFRSF & $\begin{array}{l}\text { Procedural due } \\
\text { process }\end{array}$ & 2005 \\
\hline $\begin{array}{l}\text { Leaders of international organizations appointed to advise Trustees } \\
\text { http://www.ifrs.org/Archive/Press-Relases- } \\
\text { Archive/2005/Pages/Leaders-of-international-organisations- } \\
\text { appointed-to-advise-Trustees.aspx }\end{array}$ & IFRSF & $\begin{array}{l}\text { Procedural due } \\
\text { process }\end{array}$ & 2005 \\
\hline $\begin{array}{l}\text { IASB expands its working group on Standards for Smaller Entities } \\
\text { http://www.ifrs.org/Archive/Press-Relases- } \\
\text { Archive/2005/Pages/IASB-expands-its-working-group-on- } \\
\text { Standards-for-Smaller-Entities.aspx }\end{array}$ & IFRSF & $\begin{array}{l}\text { Procedural due } \\
\text { process }\end{array}$ & 2005 \\
\hline $\begin{array}{l}\text { Trustees invite comment on IASB's Due Process Handbook and } \\
\text { IFRIC Review of Operations } \\
\text { http://www.ifrs.org/Archive/Press-Relases- } \\
\text { Archive/2005/Pages/Trustees-invite-comment-on-IASBs-Due- } \\
\text { Process-Handbook-and-IFRIC-Review-of-Operations.aspx }\end{array}$ & IASB & $\begin{array}{l}\text { Procedural due } \\
\text { process }\end{array}$ & 2005 \\
\hline
\end{tabular}




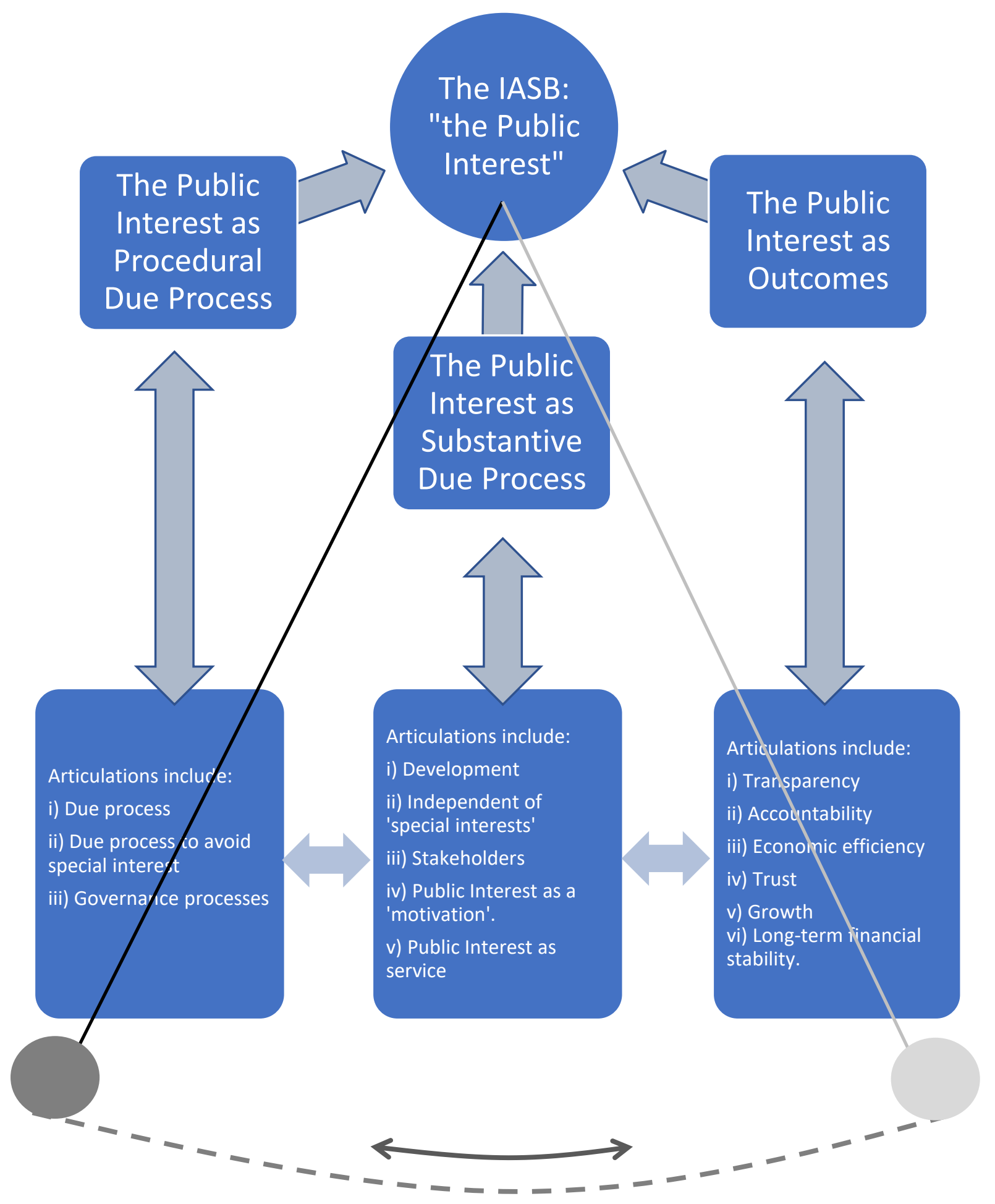

Figure 2: The "Public Interest" Pendulum 